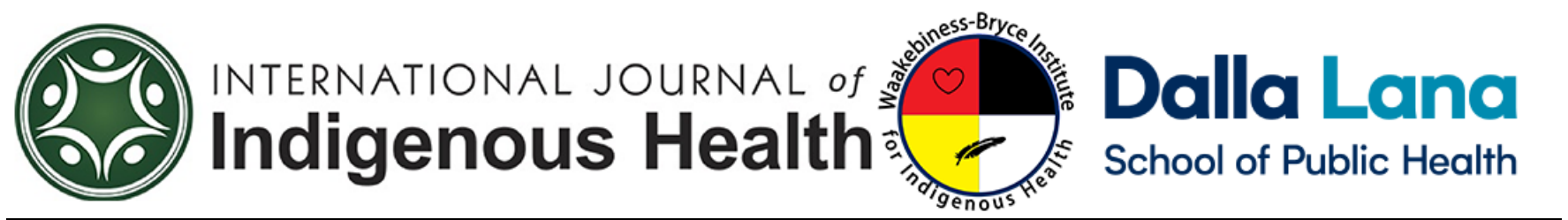

Volume 14

Issue 2. Growing Roots of Indigenous Wellbeing

Article 10

Full Issue DOI: 10.32799/ijih.v14i2.32958

October 2019

\title{
Results of a Culturally Relevant, Physical Activity-Based Wellness Program for Urban Indigenous Women in Alberta, Canada
}

\section{Sonja Wicklum, MD CCFP FCFP,}

Department of Family Medicine, University of Calgary, Institute for Public Health, University of Calgary.

sonja.wicklum@ucalgary.ca

\section{Megan Sampson}

Department of Anthropology, University of Calgary.

mbsampso@ucalgary.ca

\section{Rita Henderson, MA PhD,}

Department of Family Medicine, University of Calgary, O’Brien Institute for Public Health, University of Calgary; Department of Community Health Sciences, University of Calgary.

rihender@ucalgary.ca

\section{Shelley Wiart,}

Department of Sociology, University of Athabasca.

swiart1@athabasca.edu

\section{Grace Perez, MSc}

Department of Family Medicine, University of Calgary.

ggperez@ucalgary.ca

\section{Ashlee McGuire, PhD,}

Department of Family Medicine, University of Calgary.

ashlee.mcguire@albertahealthservices.ca

\section{Erin Cameron, PhD,}

Northern Ontario School of Medicine, ercameron@nosm.ca 


\section{Elsy Willis,}

Department of Human Biology, University of Toronto.

elsy.willis@mail.utoronto.ca

\section{Lynden (Lindsay) Crowshoe, MD,}

Department of Family Medicine, University of Calgary; Department of Community Health Sciences, University of Calgary.

crowshoe@ucalgary.ca

\section{Kerry McBrien,}

Department of Family Medicine, University of Calgary; O'Brien Institute for Public Health, University of Calgary; Department of Community Health Sciences, University of Calgary.

kamcbri@ucalgary.ca

Follow the International Journal of Indigenous Health at:

https://jps.library.utoronto.ca/index.php/ijih/index

\section{Recommended Citation}

Wicklum, S., Sampson, M., Henderson, R., Wiart, S., Perez, G., Cameron, E. ... \& McBrien, K. (2019). Results of a Culturally Relevant, Physical Activity-Based Wellness Program for Urban Indigenous Women in Alberta, Canada. International Journal of Indigenous Health, 14(2), 169 - 204. DOI 10.32799/ijih.v14i2.31890 


\title{
Results of a Culturally Relevant, Physical Activity-Based Wellness Program for Urban Indigenous Women in Alberta, Canada
}

\begin{abstract}
Colonization, racism, and resulting policies have fractured familial and intergenerational relationships. For many Indigenous women in Canada, these forces continue to create socioeconomic inequality that play out in nutritional insecurity and lack of access to physical activity resources, in turn undermining overall wellness. Women Warriors (WW), an eight-week physical activity-based wellness program, was designed to support Indigenous women's efforts to increase physical activity levels, improve nutrition, and develop support systems for improved health. Notably, it offered access to exercise instruction and facilities that may have otherwise been inaccessible to participants. To evaluate the impact of the program, we completed a mixed method pre/post evaluation of four program sessions, from January to December 2016. The WW program resulted in increased weekly pedometer step counts, increased nutrition skill acquisition, and improved confidence in exercising as a group and increased consumption of fruit and vegetables. The program also produced improvements in anthropometric measures and a reduction in blood pressure values. Participants developed positive social support systems and were introduced to health and social resources in their community. They reported appreciating that the program motivated them by way of accountability to others and offered opportunity to share experiences in sharing circles. The program identified barriers to health change, including lack of resources that support physical activity, healthy eating, and personal stress management. Participants recommended increasing the program's duration and intensity, enhancing the nutrition and health education offered, and increasing opportunities for socialization and relationship building. The WW program was well received and shows promise as a practical, community-based method to support Indigenous women interested in increasing positive health behaviours.
\end{abstract}

\section{Keywords}

\section{Indigenous, physical activity, health promotion, women, wellness, weight management}

\section{Creative Commons License}

\section{(C) $\Phi \otimes \Theta$}

This work is licensed under a Creative Commons Attribution-Noncommercial-No Derivative Works 4.0 License. 


\section{Acknowledgements}

The Women Warriors program acknowledges and greatly valued the support of the Lloydminister Native Friendship Network including Bonnie Start, Executive Director and Melva Tootoosis, Elder. We also acknowledge all of the participants of the Women Warriors program for supporting the evaluation.

Funding: Recreation and Physical Activity Division of the Government of Alberta, Canada. Trial Registration: ISRCTN15605975, https://doi.org/10.1186/ISRCTN15605975

\section{Introduction}

\section{Sociopolitical Setting}

The Truth and Reconciliation Commission (TRC) of Canada acknowledges the impact of the residential school system in Canada, which separated hundreds of thousands of Indigenous children from their families and communities from 1840-1996. The report highlights how colonization, through residential schools, child welfare, and other assimilationist systems, have caused significant personal and collective trauma (Elias et al., 2012; Heart, Chase, Elkins \& Altschul, 2011; TRC, 2015). It builds upon a growing body of evidence that illustrates how trauma resulting from colonization contributes to increased psychological stress, mental health issues and addictions at the individual level, including distrust in healthcare relationships (Jacklin et al., 2017). Moreover, trauma and its associated effects may be passed on intergenerationally, and even yield harmful physical changes due to epigenetic phenomena of gene methylation (Johnstone \& Baylin, 2010; Murgatroyd, Wu, Bockmuhl \& Spenger, 2010; Yehuda et al., 2016). There is therefore a strong need for supportive infrastructures to promote healthy behaviours and activities.

With over 6000 testimonies by residential school survivors, the TRC's final report contains 94 Calls to Action focused on reorienting all sectors, institutions, and levels of society towards reconciliation (TRC, 2015). Calls to Action numbers 88 and 89 emphasize the need to reduce barriers to Indigenous participation in physical activity and sport, and to create inclusive and culturally relevant physical activity policies, programs, and initiatives. Such participation is important given higher rates of obesity and associated diabetes and cardiovascular disease within Indigenous communities (Anand et al., 2001; Assembly of First Nations/First Nations Information Governance Committee, 2007; Diabetes Canada Clinical Practice Guidelines Expert Committee et al., 2018; Heart Research Institute, 2017; Prince et al., 2018; Tjepkema, 2005; Public Health Agency of Canada [PHAC], 2011a; Young, Reading, Elias, \& O'Neil, 2000). These diseases are increasingly recognized as being shaped by sociopolitical factors in addition to genetic predisposition, particularly nutrition, physical activity, and changed relationships to the environment. 


\section{Indigenous Women and Obesity}

In an Atlantic Centre of Excellence for Women's Health's (2009) literature review of Indigenous women and obesity in Canada, the authors note that "very little research provide[s] any historical or political context" for the issue of higher rates of obesity among this diverse population (Atlantic Centre of Excellence for Women's Health [ACEWH], 2009). Defined as a body mass index (BMI) of $>30 \mathrm{~kg} / \mathrm{m} 2$, the prevalence of obesity among Indigenous women is higher $(24.5 \%$ Metis $-41.1 \%$ First Nations on-reserve) than in the Canadian female adult population (23.4\%), a pattern repeated for Type 2 diabetes and cardiovascular disease (Anand et al., 2001; ACEWH, 2009; Canadian Diabetes Association Clinical Practice Guidelines Expert Committee et al., 2013; Chowdhury et al., 2016; Navaneelan \& Janz, 2014; Oster, Mayan, \& Toth, 2014; PHAC, 2011; PHAC, 2011b; Prince et al., 2018; Young et al., 2000). While the typically associated factors of poor nutrition and low levels of physical activity are often framed as "lifestyle choices" by government agencies and health professionals, such factors must be contextualized. While nutrition and physical activity levels shape disease, social and economic factors can constrain capacity to even make choices to promote wellness in the first place. While much variation exists between the traditions, customs, and beliefs of Indigenous people, women in many precolonial Indigenous communities were essential to the economic and cultural survival of their households and communities. Their roles were typically viewed as balanced with, and complementary to, those of men (Halseth, 2013; Kenney, Faries, Fiske, \& Voyageur, 2004). However, patriarchy has been a central tenant of colonial structures, and its imposition has led Indigenous women to be treated as "an inferior gender within [an] inferior class" (Halseth, 2013). This is reflected in discriminatory legislation that for the better part of the twentieth century disenfranchised Indigenous women and stripped them of their property rights. In Canada, despite the passing of bills designed to remediate this including Bill C-31 in 1985 and subsequently Bills C3 (2011) and S3 (2017)--the detrimental social, economic, and political effects of prior legislation continue to be felt by Indigenous women. Bourrassa, McKay-McNabb, \& Hampton (2004) argue that understanding and addressing these factors should be of primary concern to those aiming to explain and address health inequity, claiming:

We must re-examine data that suggests Aboriginal women are excessively vulnerable to [poor health] and violence/abuse in light of how colonization and postcolonial processes have conferred risks to the health of Aboriginal women, and barriers to accessing quality healthcare. It is these risks and barriers that contribute to rates of morbidity and mortality that are well above those of the average Canadian woman. (p. 27)

\section{Incorporating Indigeneity into Program Design}

Few individuals $(9 \%-27 \%)$ in the general population achieve recommended physical activity (PA) levels (Colley et al., 2011; Foulds, Warburton, \& Bredin, 2013). While economic and political 
barriers may restrict access to health-promoting spaces and opportunities (e.g., safe neighborhoods, well-funded education systems), increasing opportunities to access PA is one means of mitigating the harms of obesity and related diseases in Indigenous communities. PA is known to reduce cardiovascular disease, diabetes, and cancer risk and improve insulin sensitivity and blood glucose levels in people with diabetes (American Diabetes Association, 2004; World Health Organization, 2018). However, the health disparities endured by Indigenous women require tailored and culturally responsive approaches to health promotion (ACEWH, 2009; Native Women's Association of Canada, 2012; Ziabakhsh et al., 2016). A review of PA programming for Indigenous women demonstrates that such programming should be grounded in knowledge about, and appreciation for, regional Indigenous histories, cultures, and values. It suggests this can be achieved through incorporating Indigenous facilitators and instructors, traditional foods and varieties of PA, and other cultural components, such as the specific wellness frameworks of particular communities, into programming (Wicklum et al., 2018). A recent review of PA-based interventions for diabetes prevention and management for Indigenous people by Rice et al. (2016) identified 13 interventions focused mainly in rural settings and on school-aged children. Only three of the 13 interventions indicated sustained increase in PA levels, and they concluded there was a need for well-studied interventions that are culturally responsive in design. Similar reviews of PA-based programming for Indigenous people in Australia and New Zealand (Sushames, van Uffelen, \& Gebel, 2016) and the United States (Teufel-Shone, Fitzgerald, Teufel-Shone, \& Gamber, 2009) also emphasized the importance of cultural relevance in PA programming.

Women Warriors (WW) was developed to address the health risks posed by increased rates of obesity and diabetes among Indigenous women. It uses a community-based and culturally relevant approach, seeking to empower Indigenous women in their attempts to combat factors contributing to ill health via physical activity, nutrition, peer support, and additional resources that meet their distinct needs. Inclusion and reconciliation are founding principles of the program.

WW was developed collaboratively with Indigenous women, for Indigenous women (and is made open to a minority of non-Indigenous peers when space permits). It derives from the vision of a local Métis woman with roots to the North Slave Métis Alliance in the Northwest Territories and the local Native Friendship Centre. The women in the community recognized the need for low-barrier, Indigenous-focused programming in their city, which prompted their collaboration with a team at the University of Calgary. These partnerships established the importance of developing a local advisory council of Elders and community leaders when adapting a WW program for a new community and secured Recreation and Physical Activity Project Grant funding from the Government of Alberta to develop and run the program. The program has since been scaled in several new settings, both on rural First Nation reserves and in urban settings in Alberta. In each case, local Indigenous organizations or governments have been directly involved in tailoring and delivering the program to suit the needs of 
their distinct communities. Evaluation of the program has prioritized the voices of the Indigenous women who contribute, and emerging program developments are based directly on this feedback.

This paper presents findings from a mixed methods, pre/post-evaluation of the WW program first offered in 2016. This evaluation contributes to the growing body of literature showing that cultural components in wellness programs are equally as important as physical activity components (Lavallée, 2007; Lavallée, 2008) and that multifaceted programming leads to greater successes with respect to healthy behaviours.

\section{Methods}

From January to December 2016, we conducted an evaluation of four iterations of WW's "Eight Weeks to Healthy Living" program.

\section{Recruitment and Consent}

Prior to starting the study, ethics approval was obtained through the Conjoint Health Research Ethics Board at the University of Calgary (REB: 15-2452). Participants first enrolled in the program, following which study consent was obtained. The facilitator was blinded to who consented, and participation was not dependent on consent. Pre- and post-program questionnaires were completed. When the program ended, participants volunteered to participate in qualitative interviews. The interviewer randomly selected individuals who agreed to be contacted. Consent was obtained for the qualitative, semi-structured group and individual interviews.

\section{Study Participants}

All participating individuals consented to the research. Study participants were women ages 1865 years who lived in Lloydminster, Alberta, or in neighbouring communities and reserves. Pregnant or breast-feeding women and women presently in/on a diet program were excluded. The Physical Activity Readiness Questionnaire was used to assess health risk prior to admission to the program in order to ensure the safety of participants (Adams, 1999; Warburton et al., 2011).

\section{Location}

The 2016 WW program was piloted in the small Canadian city of Lloydminster, Alberta. Lloydminster has fewer than 32,000 residents, with approximately $10 \%$ reporting Indigenous background. Few sports leagues or facilities offer affordable or accessible options for residents to engage in physical activity, something that motivated WW developers to fill this gap. 


\section{Program Description}

The WW program consisted of eight weekly sessions. Two pre-program sessions included a program orientation and an optional presentation on smoking cessation. During orientation, the concept of the medicine wheel was reviewed and a sharing circle demonstrated by a community Elder, research consent and pre-program data collection was completed, and individuals were taught how to set SMART goals. SMART goals support individuals in setting specific, measurable, and attainable goals.

Theoretical rationale inspiring the program's design included the concept of goal setting, found helpful in behavior change theory (Shilts, Horowitz, \& Townsend, 2004; Werch et al., 2007) along with the promotion of self-efficacy, health literacy, and connectedness (Chao, Lin, \& Ma, 2019; Mead, Gittelsohn, Roache, Corriveau \& Sharma, 2013; Mohatt, Fok, Burket, Henry, \& Allen, 2011; Rowlands, Shaw, Jaswal, Smith \& Harpham, 2017; Shaw, Huebner, Armin, Orzech, \& Vivian 2009). In addition, social cognitive theory addresses the way in which program participants acquired and maintained behavior within the specific social environment of the program.

The last of the eight weekly sessions included an 'end-of-program' celebration and completion of post-program data collection.

Each weekly session started with 45-60 minutes of group exercise of various types, including yoga, Pilates, kickboxing, Nordic walking (i.e., urban poling), POWFit, aerobics, and Zumba classes. Diverse certified fitness instructors lead each session. All instructors were previously trained in issues of race, weight, and gender bias to ensure a safe, sensitive environment. Nutrition education included a review of Canada's food guide recommendations for vegetable and fruit consumption, practical demonstrations to increase knowledge about sugar, fiber, and protein content of common foods, an introduction to local nutrition resources, and strategies to facilitate healthy eating. These are short sessions of 15-20 minutes each week. Guest healthcare providers were introduced to the group to deliver brief education on specific topics according to participant interests. Examples included local diabetes educators, pelvic floor physiotherapists, gardeners, and psychologists. Sessions ended with 15-45 minutes of sharing circle discussions about either a set topic or participants' challenges or successes over the past week. In addition to a private Facebook group, the sharing circles provided a forum to explore and support emotional, mental, and spiritual components of holistic health. Participants were able to directly contact the Elder involved in the program and the facilitator informed participants of other gatherings or supports available in the community.

Participants received a PiezoX ${ }^{\mathrm{TM}}$ pedometer at the first session, and step counts were recorded weekly throughout the program. Pedometers were chosen to assess PA, as they were successfully used in earlier WW pilot programs as a cost effective and validated way to provide immediate motivational feedback to participants (Colley et al., 2013; Colley et al., 2011; Colley, Janssen, \& Tremblay, 2012). 
Participants were permitted to keep the pedometers when the program ended to continue their motivation.

The evaluation focused on the program's impacts in terms of: 1) improved PA levels, 2) enhanced nutritional knowledge, and 3) increased social support and capacity for community building.

\section{Impact Evaluation Data}

Body weight, waist circumference, and blood pressure were measured at orientation and the final session. Height was measured at orientation only. Pre- and post-program questionnaires were also administered at these times. Body weight $(\mathrm{kg})$ was measured with the Tanita Weight and Body Composition Scale SC-240, and height (m) measured using a 200HMP Poststad Portable Stadiometer. BMI was calculated as an indirect measure of body fat. Although limited in its correlation to body fat, BMI was nevertheless used to represent a pragmatic means of evaluating change before and after the program (Romero-Corral et al., 2008). At orientation and the final session, waist circumference $(\mathrm{cm})$ was completed twice and averaged on each individual, and blood pressure was recorded using the BPTRU Blood Pressure Cuff (434-BPM-200-NA). Additionally, approximately one-quarter of all participants across all programs were invited to open-ended interviews on their experiences, where they explored barriers and challenges to meeting their nutritional and activity goals, facilitators, program strengths, and recommendations for future programming. They addressed successes experienced and methods envisioned for motivating others to make similar life improvements. These individual and group interviews, carried out by a researcher at the University of Calgary independent from the program design or implementation, lasted 25-45 minutes.

\section{Analysis}

Self-report pedometer logs were analyzed using repeated measures of variance. Anthropometric measurements and blood pressures were reported as means and ranges, and paired changes pre/post program were evaluated. Pre/post responses to questions pertaining to confidence in fruit and vegetable consumption and exercising in a group were measured using a 10-point Likert scale, and paired changes were evaluated. Semi-structured individual and group interviews were undertaken with 21 participants, approximately five individuals from each program, within two weeks following the end of each. Participants were asked open-ended questions. Participant interviews were transcribed verbatim by one researcher $(\mathrm{RH})$ and then reviewed by two researchers (RH and $\mathrm{SW}$ ). Inductive thematic analysis was completed using structural coding to generate themes in each of the key areas (i.e., barriers, facilitators, successes). 


\section{Results}

\section{Demographic Profile}

Attendance and demographics. Table 1 outlines attendance and participant characteristics across the four programs. The results of all categories were based on self-reported responses to the pre-program questionnaire completed by study participants at the beginning of the program (Appendix). Attendance was full for each session: Winter $(\mathrm{n}=18)$, Spring $(\mathrm{n}=33)$, Summer $(\mathrm{n}=21)$, Fall $(\mathrm{n}=20)$, and each session had a waitlist. Over the entire year, a total of 66 participants attended the program for the first time; $100 \%$ consented to research, $26 \%$ of these attended fewer than three sessions and were excluded from analysis. Reasons for not attending included lack of childcare or transportation, health crises, including hospitalization and mental health issues, family crises and commitments, and other life stressors. Analysis was completed on individuals who took the program for the first time and those who attended a minimum of $3 / 8$ of the weekly sessions $(n=49)$. The mean age was 37.3 years, mean BMI $32.8 \mathrm{~kg} / \mathrm{m} 2$, and $49 \%$ were Indigenous.

\section{Physical Activity.}

Baseline PA was assessed using pre/post-program questionnaires (Table 2). Approximately half of first-time participants $(27 / 49,55 \%)$ indicated they had been prevented from doing physical activity in the last three months. The most common reasons given for not engaging in physical activity were lack of interest $(15 / 24,54 \%)$, weight $(8 / 24,33 \%)$, arthritis or joint pain $(6 / 24,25 \%)$, and recent trauma or injury $(2 / 24,8 \%)$. Based on the results of pre-program questionnaires, only $14 \%$ of participants indicated they used a pedometer prior to entering the program. Average weekly step count increased from Week 1 to Week $8(p=0.001)$ during the program, and this trend was similar across the two ethnic groups of participants. 


\section{Table 1}

\section{Demographic Profile of Participants}

\begin{tabular}{|c|c|c|c|c|c|}
\hline $\begin{array}{l}\text { Demographic Profile } \\
\text { Program participants }\end{array}$ & $\begin{array}{c}\text { Winter } \\
\text { Program }\end{array}$ & $\begin{array}{c}\text { Spring } \\
\text { Program }\end{array}$ & $\begin{array}{l}\text { Summer } \\
\text { Program }\end{array}$ & $\begin{array}{c}\text { Fall } \\
\text { Program }\end{array}$ & Total \\
\hline First time & $18(27 \%)$ & $26(39 \%)$ & $13(20 \%)$ & $9(14 \%)$ & $66(100 \%)$ \\
\hline Second time & & $7(35 \%)$ & $8(40 \%)$ & $5(25 \%)$ & $20(100 \%)$ \\
\hline Third time & & & & $6(100 \%)$ & $6(100 \%)$ \\
\hline Attendance (first timers) $^{\mathrm{a}}$ & & & & & \\
\hline$<3$ sessions & $3(17 \%)$ & $6(23 \%)$ & $7(54 \%)$ & $1(11 \%)$ & $17(26 \%)$ \\
\hline $3+\operatorname{sessions}$ & $15(83 \%)$ & $20(77 \%)$ & $6(46 \%)$ & $8(89 \%)$ & $49(74 \%)$ \\
\hline Number of sessions attended ${ }^{b}$ & & & & & \\
\hline 3 & $1(7 \%)$ & $3(15 \%)$ & $1(17 \%)$ & $2(25 \%)$ & $7(14 \%)$ \\
\hline 4 & $3(20 \%)$ & $2(10 \%)$ & $2(33 \%)$ & $2(25 \%)$ & $9(18 \%)$ \\
\hline 5 & $4(27 \%)$ & $7(35 \%)$ & $1(17 \%)$ & $3(38 \%)$ & $15(31 \%)$ \\
\hline 6 & $1(7 \%)$ & $3(15 \%)$ & $2(33 \%)$ & & $6(12 \%)$ \\
\hline 7 & $6(40 \%)$ & $4(20 \%)$ & & $1(12 \%)$ & $11(22 \%)$ \\
\hline 8 & & $1(5 \%)$ & & & \\
\hline Mean \pm SD & $5.53 \pm 1.41$ & $5.30 \pm 1.46$ & $4.67 \pm 1.21$ & $4.50 \pm 1.31$ & $5.16 \pm 1.41$ \\
\hline $\operatorname{Age}^{\mathrm{b}}$ & & & & & \\
\hline $\begin{array}{r}\text { Mean } \pm \text { SD } \\
\text { Range (min - max })\end{array}$ & $\begin{array}{c}34.21 \pm 11.2 \\
(13-50)\end{array}$ & $\begin{array}{l}39.01 \pm 13.2 \\
(17-61)\end{array}$ & $\begin{array}{c}29.02 \pm 5.0 \\
(23-34)\end{array}$ & $\begin{array}{l}44.06 \pm 17.4 \\
(16-70)\end{array}$ & $\begin{array}{l}37.27 \pm 13.2 \\
(13-70)\end{array}$ \\
\hline Body mass index (baseline) ${ }^{\mathrm{b}}$ & & & & & \\
\hline Mean \pm SD & $32.88 \pm 5.5$ & $33.15 \pm 6.3$ & $30.19 \pm 8.5$ & $33.51 \pm 6.4$ & $32.76 \pm 6.3$ \\
\hline Range (min - max) & $(21-42)$ & $(23-45)$ & $(22-46)$ & $(26-43)$ & $(21-46)$ \\
\hline Ethnicity $^{\mathrm{b}}$ & & & & & \\
\hline Indigenous (self-identified) & $11(73 \%)$ & $4(20 \%)$ & $4(67 \%)$ & $5(62 \%)$ & $24(49 \%)$ \\
\hline Non-Indigenous & $4(27 \%)$ & $16(80 \%)$ & $2(33 \%)$ & $3(38 \%)$ & $25(51 \%)$ \\
\hline Resides on a reserve $^{c}$ & $1(9 \%)$ & $0 \%$ & $0 \%$ & $2(40 \%)$ & $3(12 \%)$ \\
\hline Heart disease & $3(20 \%)$ & $3(15 \%)$ & $0 \%$ & $0 \%$ & $6(12 \%)$ \\
\hline Diabetes mellitus & $1(7 \%)$ & $0 \%$ & $0 \%$ & $1(12 \%)$ & $2(4 \%)$ \\
\hline Bone/joint disease & $1(7 \%)$ & $2(10 \%)$ & $0 \%$ & $0 \%$ & $2(4 \%)$ \\
\hline Liver disease & $1(7 \%)$ & $0 \%$ & $0 \%$ & $0 \%$ & $1(2 \%)$ \\
\hline Mental illness & $1(7 \%)$ & $4(20 \%)$ & $1(17 \%)$ & $1(12 \%)$ & $6(12 \%)$ \\
\hline Prescription medications ${ }^{\mathrm{b}}$ & $5(33 \%)$ & $7(35 \%)$ & $3(50 \%)$ & $1(12 \%)$ & $16(33 \%)$ \\
\hline Tobacco/cigarette use $\mathrm{e}^{\mathrm{b}}$ & $5(33 \%)$ & $7(35 \%)$ & $0 \%$ & $3(38 \%)$ & $15(31 \%)$ \\
\hline Alcohol use $e^{b}$ & $7(47 \%)$ & $10(50 \%)$ & $2(33 \%)$ & $1(12 \%)$ & $20(41 \%)$ \\
\hline
\end{tabular}

Denominator $=$ women who joined program for first time.

$\mathrm{b}$ Denominator $=$ women who joined for first time and attended at least 3 of 8 program sessions. c Denominator $=$ Indigenous women who joined for first time and attended $3+$ sessions of program.

Note: The results of all categories were based on self-reported responses to the pre-program questionnaire completed by study participants at the beginning of the program. 


\section{Table 2}

Baseline Data and Program Outcomes Related to Physical Activities

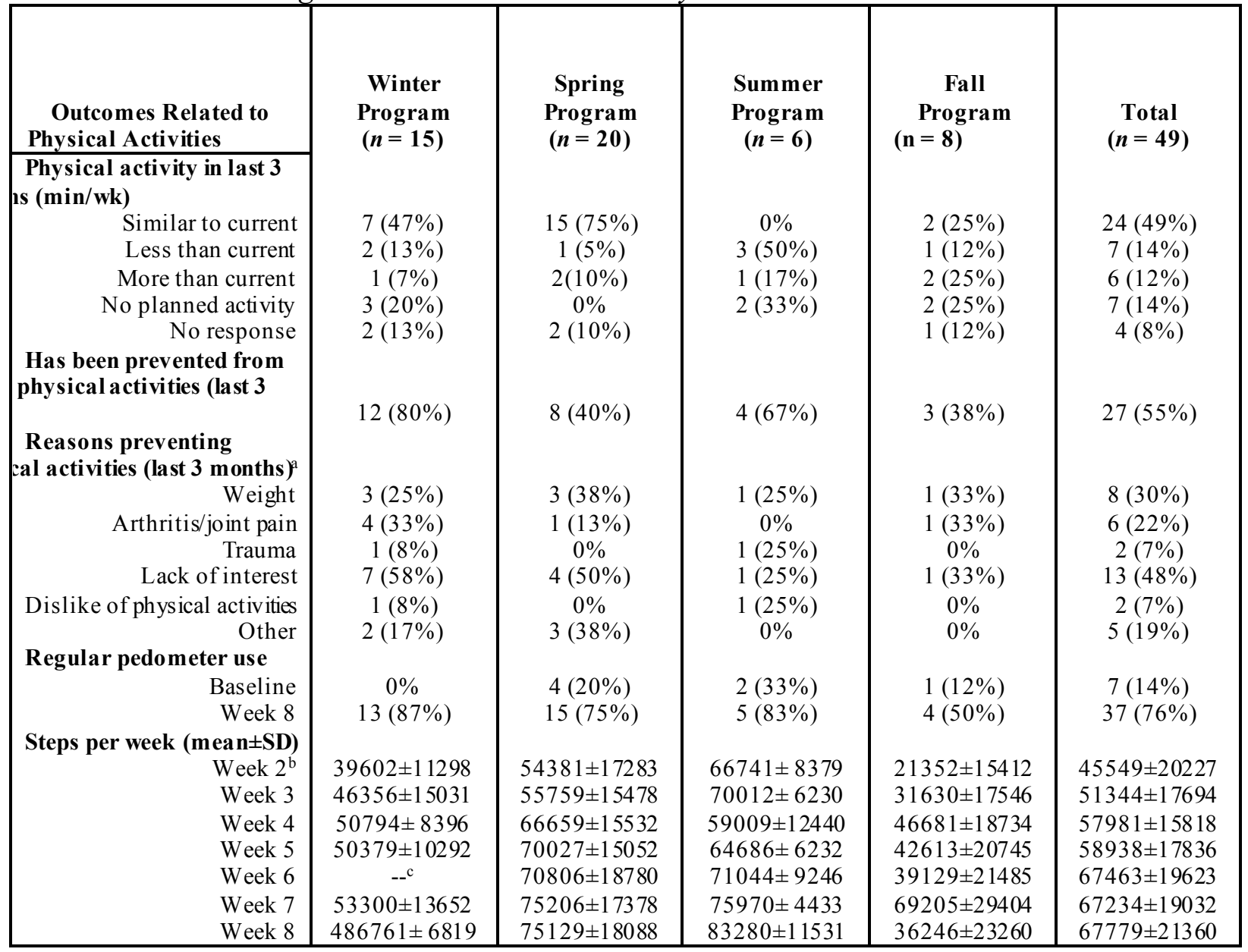

${ }^{\text {a }}$ Denominator $=$ women who said they have been prevented from doing physical activities in last 3 months.

$\mathrm{b}$ There is no Week 1 information, as Week 2 of the program was the first day of step count collection.

c There is no Week 6 Winter Program information, as the program was cancelled due to a major community event and the facilitator was unable to follow up with participants. 


\section{SMART goals.}

More than half $(28 / 49,57 \%)$ of first-time participants indicated their physical activity goals were achieved during the program. Similarly, 53\% (26/49) indicated their nutritional goals were achieved.

\section{Confidence in activities for healthy living.}

Comparing individuals' pre and post program showed statistically important improvements in confidence to participate in group exercises $(p=0.042)$ and confidence in eating at least five servings of fruits and vegetables per day $(p=0.002)$.

\section{Themes arising from participant interviews}

Barriers. In individual and group interviews, consistent themes were identified with respect to both barriers and facilitators to making nutritional and activity changes. Broadly, persistent adversities in participants' lives highlight how family networks could act both as motivators and barriers to personal wellness within the context of resource disparities. Understanding personal responsibilities in the lives of these women helps to identify particularly supportive mechanisms within the WW programs and target recommendations for similar programming.

Barriers were most often due to inadequate finances, personal stress, and non-existent or inadequate support from other family members or their communities.

"Family gatherings, food. Kids, 3 grand babies, and 2 older ones. Have to attend to the babies. Restricts time available to focus on self. Focusing on everybody else other than me. Pretty much have to go MIA to think about me." - Participant 1, 2016.

On depression and its impact on signing up for a program:

"You don't want to cuz of fear and fear of judgement. Zero motivation" - Participant 2, 2016.

Participants identified the high cost of food, prohibitive costs of accessing facilities for PA, and lack of familiarity or sense of security with PA infrastructure in their communities as barriers to sustaining behavior changes. Roles as mothers and grandmothers were key motivators for multiple women in each of the four groups to commit to their goals, although the pressures of caring for youth could undermine meeting these same goals. Despite care for families often being constrained by shift work that would lead to exhaustion, the eight-week structure of the program was a manageable commitment for the three-quarters of original enrollees who persisted. Some even noted the role of the program in reclaiming balance despite such barriers. 
Importantly, disparities were often direct and indirect effects of colonization on their communities, as some women struggled to avoid having their grandchildren taken into child welfare custody as their own children struggled with addiction; others experienced homicides in their close family networks during the program. Despite family pressures, those with limited social networks disclosed struggling with regular attendance, and negative healthcare issues experienced by many participants led to a common aversion to seeking primary care support for any health conditions. Injuries, or loss of strength post-partum, along with depression and medications, were common barriers to making healthy nutritional and activity changes in their lives.

Supports. Facilitators to participation and adopting nutritional and activity changes included family supports and developing a sense of community among participants. These supports offered the opportunity to socialize, with family motivating attendance and helping some overcome personal resistance to attending.

"Get help with a bunch of other women in same boat as me. Gives more ambition / motivation to do it. Seeing 34 and 60 year old women doing these jumping jacks can make you want to do it. That's something that interested me, it was young and old, all different age groups." - Participant 3, 2016.

Opportunities offered through WW to access educational resources, be accountable to other women in the same process, and model behaviour for future generations helped participants move on their PA goals despite limitations in their immediate lives. Of note is that as many as one-quarter of participants travelled to the program from nearby First Nation reserves, sometimes driving more than an hour each way to attend.

Positive mechanisms. Key program strengths identified in interviews were that there was no cost to participants and no prerequisite health conditions to qualify (some diabetes programs in area health centres were described as requiring a diagnosis to participate). The program also seemed to foster a sense of solidarity among women, where many felt relieved that men were not involved, allowing for more comfort in their own bodies. The multigenerational aspect of the program was uplifting, as age did not always correspond to capacity for PA.

Some participants appreciated that the program increased their awareness of affordable gym and pool options, while others appreciated learning about the accessibility, feasibility, and physical benefits of urban poling (i.e., Nordic walking). All participants noted the key role of the facilitator in keeping them motivated. Some expressed feeling energized to help others, although common themes were over commitment and ensuring they could keep up the new changes in their own lives. Nutritional handouts enabled multiple women to educate peers and family members around the materials covered, although 
several expressed a desire that more program time be committed to nutritional education. They suggested this occur at a time separate from the physical exercise component of the program, after which they often felt too exhausted to pay attention. Meal plans and recipes helped a few women try new foods or reduce compulsive eating habits. Positive steps also were observed for water intake.

Personal success. Through the program, participants learned to identify nutritional and activity changes within their control. Successes experienced over the course of the eight weeks encouraged the women to stay committed to the program and continue healthy eating and activities afterward. Noticeable weight loss was an important indicator for most women alongside other health improvements, with some noting they had lowered blood pressure and cholesterol, improved energy, and decreased back or joint pain. Outside of physical improvements, the women enjoyed undoing their unhealthy habits. Learning how to meal plan was noted as valuable among interviewees from all groups, with some expressing surprise around what they had previously thought was healthy eating that might actually undermine them in meeting weight goals. Many also appreciated the noticeable impact integrating step counting and carrying a bottle of water with them could have on their energy level throughout the day.

Recommendations. Participants felt social support could be further harnessed to motivate others through the program. The chance to network with other women was a strong facilitator of wellness, which helped some compensate for lack of family/social support. Several women suggested their group could better network with each other outside weekly meetings to involve others in their health journeys (e.g., for Saturday urban poling activities). One woman suggested that by planning health activities as a group outside of class, like walking to the program, everyone could have greater control of their weight loss while experiencing support by others in similar situations. Having a buddy or group of peers in the program made many women feel responsible to remain committed not only for herself, but also for others. The women interviewed emphasized that the program could enhance motivation to overcome barriers to joining or sustaining changes by harnessing ways to further incorporate group support and access to health and nutritional experts throughout their coming together

Additional recommendations included a desire to meet more than once a week (recognizing this could be prohibitive to some), to have more time to interact with experts to answer questions, to receive more specific nutritional instructions instead of general guidance, and to make it more accessible for women living in nearby First Nations communities. See Table 3 for a summary of qualitative themes and representative participant quotes. 
Table 3

Emergent Themes from Individual and Group Interviews

\begin{tabular}{|c|c|c|c|c|}
\hline Supports & Barriers & $\begin{array}{l}\text { Personal } \\
\text { Success }\end{array}$ & $\begin{array}{c}\text { Positive Mechanisms } \\
\text { men Warriors Program }\end{array}$ & \begin{tabular}{|l} 
Recommendations to \\
Enhance Outcomes
\end{tabular} \\
\hline $\begin{array}{l}\text { - Family } \\
\text { support/desire to } \\
\text { model for children } \\
\text { and be well for future } \\
\text { family } \\
\text { - Socialization/ sense } \\
\text { of community among } \\
\text { fellow participants } \\
\text { - Accountability } \\
\text { through regular group } \\
\text { sessions } \\
\text { - Educational } \\
\text { resources to bring to } \\
\text { one's wider social } \\
\text { networks }\end{array}$ & $\begin{array}{l}\text { - Inadequate or } \\
\text { inaccessible } \\
\text { physical activity } \\
\text { infrastructure/ } \\
\text { resources } \\
\text { - Personal stress } \\
\text { - Limited family/ } \\
\text { community } \\
\text { support } \\
\text { - High cost of } \\
\text { food } \\
\text { - Hesitations } \\
\text { around accessing } \\
\text { unfamiliar } \\
\text { facilities for } \\
\text { physical activity }\end{array}$ & $\begin{array}{l}\text { - Weight loss } \\
\text { - Improved } \\
\text { health } \\
\text { conditions } \\
\text { (e.g., lowered } \\
\text { blood pressure/ } \\
\text { cholesterol, } \\
\text { less back pain) } \\
\text { - Improved } \\
\text { energy } \\
\text { - Learning } \\
\text { skills to } \\
\text { integrate } \\
\text { healthy habits } \\
\text { (e.g., meal } \\
\text { planning, } \\
\text { carrying water } \\
\text { bottles, step } \\
\text { counting) }\end{array}$ & $\begin{array}{l}\text { - No cost to participate } \\
\text { - No prerequisite } \\
\text { health conditions to } \\
\text { qualify } \\
\text { - Women-only } \\
\text { program (promoting } \\
\text { confidence) } \\
\text { - Multigenerational } \\
\text { - Connection with } \\
\text { peers } \\
\text { - Mentorship in local } \\
\text { affordable physical } \\
\text { activity facilities }\end{array}$ & $\begin{array}{l}\text { - Further harness social } \\
\text { support (e.g., buddy } \\
\text { system) } \\
\text { - Group networking } \\
\text { outside of weekly } \\
\text { meetings } \\
\text { - Meeting more than } \\
\text { once a week for those } \\
\text { who can } \\
\text { - More interactions with } \\
\text { experts } \\
\text { - More specific health } \\
\text { and nutritional education } \\
\text { - Greater accessibility } \\
\text { for women living in } \\
\text { nearby First Nations } \\
\text { communities }\end{array}$ \\
\hline
\end{tabular}

\section{Limitations}

We found our activity questionnaire was a challenge for participants and the results obtained from this activity questionnaire could not be interpreted reliably and inhibited our ability to conduct a thorough analysis of the results (refer to Appendix for PA questions). Validated PA questionnaires such as the World Health Organization - Global Physical Activity Questionnaire may be well suited for future studies (Cleland et al., 2014). Other limitations of our program evaluation included the following: 1) the lack of long-term follow-up to determine if PA levels were sustained after the program was completed, which precludes estimating the long-term effects of the program;2) the potential source of bias introduced by the self-report nature of the pedometer logs due to selective memory and/or exaggeration, which could have affected the results; 3) the small sample size, which affects generalizability of the study findings, particularly given the specific population addressed, and which makes it difficult to find significant relationships from the data; 4) lack of a control group, meaning there is no baseline comparison to assess the program outcomes; and 5) selection bias due to the sample 
of individuals selected, which implies the women already had some degree of readiness to make changes and that positive experiences may have been influenced by research participation, or the observer effect.

\section{Discussion}

The study findings demonstrate that the WW program facilitated the learning and mobilizing of health information and health resources through its community-led approach. It is necessary for Indigenous-focused programming to respond flexibly to the complexities that may exist within the lives of participants. For example, while WW aims to educate all participants about the Canada Food Guide's guidelines for daily intake of fruits and vegetables, it is cognizant that structural barriers yield food insecurity that may interfere with dietary objectives. It is not sufficient to merely provide these guidelines within the program; information about how to most affordably access these food items, and what resources and supports may be available to help facilitate this, is also necessary. This is one example of several important considerations that may arise when designing programming for this distinct demographic. These points have been demonstrated in other studies. Afele-Fa'amuli, Katirai, \& Dignan's (2009) study of a 12-week physical activity and nutrition education program for Samoan women noted the importance of facilitators understanding the culture and catering program goals and content to align with community needs and values. Similar sentiments are reflected in McHugh and Kowalski's (2009) investigation of young Indigenous women's body image in a Saskatchewan, Canada, school where they noted that relationship building and collaboration with the community were critical to the success of the study.

WW helped participants recognize the social supports that existed in their community and develop new supports. Wellness-focused group interventions present an opportunity to promote networks of social support among participants (Ory et al., 2018; Berkman \& Krishna, 2015). It has long been theorized that rich supportive networks yield improved health outcomes and that such supports should be fostered and enhanced in public health promotion initiatives. Studies demonstrate a positive correlation between PA and social support (Lindsay et al., 2017; Tamers et al., 2011). Some scholars suggest social support is of particular significance in health promotion for women, who are more likely to look to friends and family for health information (Hurdle, 2001). This has been demonstrated among minority women (Eyler et al., 1999; Van Duyn et al., 2007), and may have direct implications for programs aimed at Indigenous communities where collectivism is culturally valued (Marrone, 2007). Afele-Fa'amuli et al.'s study (2009) describes the importance of building socialization time into wellness programming, presumably for this reason. Other wellness interventions aimed at Indigenous women, such as studies undertaken by Klomp, Dyck, \& Sheppard (2003) and Gellert, Aubert, \& Mikami (2010), similarly acknowledge the importance of socialization and the facilitation of relationship 
building within the programs studied. Our study highlights the importance of both principles described above: being community based and allowing for the development of a community of support.

An increase in weekly step counts, high rates of PA SMART goal achievement, and favorable reports by participants all suggest that WW had a positive effect on PA. We are not aware of any other programs that offer exposure to a variety of exercise types. Walking is a common exercise offered in interventions due to accessibility and low cost. Heard, Auvaa, \& Conway (2016) had success offering dance, as did Lavallée (2007) with martial arts. Although walking may be the most accessible form of exercise, some of our participants, and those in other studies, expressed concerns over safety when walking. Walking as a group seemed to mitigate the concern. Beyond walking, the other indoor, groupbased exercise classes mitigated safety risks and helped keep participants engaged due to the fun and engaging nature of the classes and the variety they offered. This exposure to various types of PA may mean participants find an activity well suited to them, one they gain confidence doing and may therefore continue to pursue after the program is completed. Importantly, participants reported increased confidence in their ability to participate in group exercises by the end of the program.

Modest improvements in body weight, BMI, and systolic blood pressure were also found in this study. While not specific goals of the program, they were often goals of the individual participants, especially body weight. In future studies, it would be useful to have longer-term follow-up to see if these changes persist once the program is completed. A large meta-analysis of multi-pronged weight loss interventions demonstrated a 10\% weight loss at one year, and a regain of half the weight lost at two years follow-up (Australian Bureau of Statistics, 2014; Aziz, Absetz, Oldroyd, Pronk, \& Oldenburg, 2015), which speaks to the challenge of maintaining weight loss, a challenge not exclusive to Indigenous populations. There are, however, few published reports of Indigenous weight loss programs. In a program for Indigenous populations in New Zealand (Bell, Swinburn, Amosa, \& Scragg, 2001) there was initial weight loss, all of which was regained at two years follow-up. However, similar studies have highlighted that despite limited weight loss, being more physically active and eating well can still be protective of future illness by lowering serum (low density lipoprotein, hemoglobin A1C) or physical (systolic blood pressure) markers of disease if these activities are maintained (Look AHEAD Research Group, 2014). These studies emphasize the challenge of long-term success in weight management and the varied factors that contribute to weight regain.

The intent of WW is to support individuals in initiating healthy behavior change. Social cognitive theory suggests that knowledge acquisition, followed by skill development and increased decisionmaking capabilities, leads to increased confidence and motivation to make healthy changes. WW attempts to initiate this process by demonstrating various types of exercises (knowledge) and giving participants an opportunity to practice these (skill development), while at the same time recognizing that 
the health-related behaviours of Indigenous women are often constrained by factors such as food insecurity, financial instability, and a lack of local infrastructure.

Nutrition education focuses on key factors known to influence health and weight, such as the nutritional value of fruits and vegetables and the sugar content of sweetened beverages and their influence on health. Information about nutritionally dense foods that are low in cost (such as lentils and frozen produce) and local resources offering affordable or subsidized foods are also incorporated into education sessions. We found increased confidence in participating in group exercises and consuming fruits and vegetables, suggesting the program may be succeeding in its goals. Future studies could potentially explore other methods of assessing health behavior change, examples of which could include dietary recall or patient activation assessment.

We used sharing circles as a forum for participants to express themselves in a safe, culturally relevant environment (see Akearok et al., 2019). While we did not measure the impact of this approach, we feel it would be a useful data collection tool. In Indigenous 'circle methodology', researchers are given permission to share what is discussed in the group (Lavallée, 2007; Restoule, 2006). Future program evaluations could consider incorporating more Indigenous Research Methods, including circle methodology or medicine wheel framework methodology, to enhance how women experience the WW program and how healthy change can be influenced (Latimer et al., 2018; Rothe, Ozegovic, \& Carroll, 2009). One of the greatest challenges is capturing the lived experience of Indigenous women, recognizing that the journey toward good health can be particularly challenging and circuitous for those who have experienced--and continue to experience--the effects of intergenerational trauma and colonialism.

\section{Conclusion/s}

The complexity of weight management and the complications secondary to obesity require a thorough understanding of the dynamic drivers affecting individuals' weight and health. This is particularly true in the case of Indigenous women, who often experience marginalization on the basis of race, sex, and socioeconomic status. As discussed in this paper, genetic predisposition and/or "lifestyle choices" are inadequate explanations for obesity-related illnesses in Indigenous populations; rather, health status is a function of the social determinants of health (King, Smith, \& Gracey, 2009). As such, programs for Indigenous women should be developed in partnership with and based on the needs of women in each unique community. The WW program shows promise as a community-based model for supporting Indigenous women to improve their health. It is grounded in community; increases selfefficacy through opportunity to learn, practice, and share in manageable increments; and increases health literacy through program contents and coordinating healthcare knowledge exchange with other healthcare providers from the community. This is all accomplished in a safe and supportive environment 
that is therapeutic, enhances connectedness, and fosters collaboration. Lastly, by connecting to aspects of Indigenous culture, participants can be affirmed in their identities and learn more about how connecting to culture may be protective of their health through restored sense of self-worth, sharing, and community support.

International Journal of Indigenous Health, Volume 14, Issue 2, 2019. 188 


\section{References}

Adams, R. (1999). Revised Physical Activity Readiness Questionnaire. Canadian Family Physician, 45, 992, 995, 1004-1005. PMID: 10216799; PMCID: PMCPMC2328306

Afele-Fa'amuli, S., Katirai, W., \& Dignan, M. (2009). Effectiveness of a pilot community physical activity and nutrition intervention in American Samoa. Californian Journal of Health Promotion, 7(1), 14-25. Retrieved from http://www.cjhp.org/Volume7_2009/Issue1/amuli.pdf

Akearok, G. H., Cueva, K., Petter, J., Stoor, A., Larsen, C. V. L., Rink, E.,...Hiratsuka, V. Y. (2019). Exploring the term "resilience" in Arctic health and well-being using a sharing circle as a community-centered approach: Insights from a conference workshop. Social Sciences, 8(2), 1-11. doi: $10.3390 /$ socsci 8020045

American Diabetes Association. (2004). Physical activity/exercise and diabetes. Diabetes Care, 27(Suppl 1), S58-S62. doi: 10.2337/diacare.27.2007.S58

Anand, S. S., Yusuf, S., Jacobs, R., Davis, A. D., Yi, Q., Gerstein, H.,...Lonn, E. (2001). Risk factors, atherosclerosis, and cardiovascular disease among Aboriginal people in Canada: The Study of Health Assessment and Risk Evaluation in Aboriginal Peoples (SHARE-AP). Lancet, 358(9288), 1147-1153. doi: 10.1016/S0140-6736(01)06255-9

Assembly of First Nations/First Nations Information Governance Committee. (2007). First Nations regional longitudinal health survey (RHS) 2002/03. The peoples' report. Retrieved from https://fnigc.ca/sites/default/files/ENpdf/RHS_2002/rhs2002-03-the_peoples_report_afn.pdf

Atlantic Centre of Excellence for Women's Health. (2009). Aboriginal women and obesity in Canada: A review of the iterature. Retrieved from https://cdn.dal.ca/content/dam/dalhousie/pdf/diff/acewomen-health/live/ACEWH_aboriginal_women_obesity_canada_lit_review_July_09.pdf

Australian Bureau of Statistics. (2014). National health survey: First results, Australia, 2014-2015. Retrieved from http://www.ausstats.abs.gov.au/Ausstats/subscriber.nsf/0/CDA852A349B4CEE6CA257F150009F C53/\$File/national\%20health\%20survey\%20first\%20results,\%202014-15.pdf

Aziz, Z., Absetz, P., Oldroyd, J., Pronk, N. P., \& Oldenburg, B. (2015). A systematic review of realworld diabetes prevention programs: Learnings from the last 15 years. Implementation Science, 10, 172. doi: 10.1186/s13012-015-0354-6 
Bell, A. C., Swinburn, B. A., Amosa, H., \& Scragg, R. K. (2001). A nutrition and exercise intervention program for controlling weight in Samoan communities in New Zealand. International Journal of Obesity and Related Metabolic Disorders, 25(6):920-927. doi: 10.1038/sj.ijo.0801619

Berkman, L.F., \& Krishna, A. (2015). Social network epidemiology. In L. F. Berkman, I. Kawachi, \& M. M. Glymour (Eds.), Social epidemiology (2nd ed). New York, NY: Oxford University Press.

Bourassa, C., McKay-McNabb, K., \& Hampton, M. (2004). Racism, sexism, and colonialism: The impact on the health of Aboriginal women in Canada. Canadian Woman Studies, 24(1), 23-30. Retrieved from https://cws.journals.yorku.ca/index.php/cws/article/viewFile/6172/5360

Canadian Diabetes Association Clinical Practice Guidelines Expert Committee, Harris, S. B., Bhattacharyya, O., Dyck, R., Hayward, M. N., \& Toth E. L. (2013). Type 2 diabetes in Aboriginal peoples. Canadian Journal of Diabetes, 37(Suppl 1), S191-196. doi: 10.1016/j.jcjd.2013.01.046

Chao, D. Y., Lin, T. M., \& Ma, W. Y. (2019). Enhanced self-efficacy and behavioral changes among patients with diabetes: Cloud-based mobile health platform and mobile app service. JMIR Diabetes, 4(2), e11017. doi: 10.2196/11017

Chowdhury T. T., Saad, N., Jun, M., Tonelli, M., Ma, Z., Barnabe, C. C. M., ...Hemmelgarn, B. (2016). Lifetime risk of diabetes among First Nations and non-First Nations people. Canadian Medical Association Journal, 188(16), 1147-1153. doi: 10.1503/cmaj.150787

Cleland, C. L., Hunter, R. F., Kee, F., Cupples, M. E., Sallis, J.F., \& Tully, M. A. (2014). Validity of the global physical activity questionnaire (GPAQ) in assessing levels and change in moderatevigorous physical activity and sedentary behaviour. BMC Public Health, 14:1255. doi: 10.1186/1471-2458-14-1255

Colley, R. C., Barnes, J. D., Leblanc, A. G., Borghese, M., Boyer, C., \& Tremblay, M. S. (2013). Validity of the SC-StepMX pedometer during treadmill walking and running. Applied Physiology Nutrition \& Metabolism, 38(5), 520-524. doi: 10.1139/apnm-2012-0321

Colley, R. C., Garriguet, D., Janssen, I., Craig, C. L., Clarke, J., \& Tremblay, M. S. (2011). Physical activity of Canadian adults: Accelerometer results from the 2007 to 2009 Canadian Health Measures Survey. Health Reports, 22(1), 7-14. PMID: 21510585

Colley, R. C., Janssen, I., \& Tremblay, M. S. (2012). Daily step target to measure adherence to physical activity guidelines in children. Medicine \& Science in Sports \& Exercise, 44(5), 977-982. doi: 10.1249/MSS.0b013e31823f23b1 
Diabetes Canada Clinical Practice Guidelines Expert Committee, Crowshoe, L., Dannenbaum, D., Green, M., Henderson, R., Hayward, M.N., \& Toth, E. (2018). Type 2 diabetes and Indigenous peoples. Canadian Journal of Diabetes, 42(Suppl 1), S296-S306. doi: 10.1016/j.jcjd.2017.10.022

Elias, B., Mignone, J., Hall, M., Hong, S. P., Hart, L., \& Sareen, J. (2012). Trauma and suicide behaviour histories among a Canadian indigenous population: An empirical exploration of the potential role of Canada's residential school system. Social Science \& Medicine, 74(10), 15601569. doi: 10.1016/j.socscimed.2012.01.026

Eyler, A. A., Brownson, R. C., Donatelle, R. J., King, A. C., Brown, D., \& Sallis, J. F. (1999). Physical activity social support and middle- and older-aged minority women: Results from a US survey. Social Science \& Medicine. 49(6), 781-789. PMID: 10459889

Foulds, H. J., Warburton, D. E., \& Bredin, S. S. (2013). A systematic review of physical activity levels in Native American populations in Canada and the United States in the last 50 years. Obesity Reviews, 14(7), 593-603. doi: 10.1111/obr.12032

Gellert, K. S., Aubert, R. E., \& Mikami J. S. (2010). Ke 'Ano Ola: Moloka'i's community-based healthy lifestyle modification program. American Journal of Public Health, 100(5), 779-783. doi: 10.2105/AJPH.2009.176222

Halseth, R. (2013). Aboriginal women in Canada: Gender, socio-economic determinants of health, and initiatives to close the wellness gap. Prince George, BC: National Collaborating Centre for Aboriginal Health. Retrieved from https://www.ccnsa-nccah.ca/docs/determinants/RPTAboriginalWomenCanada-Halseth-EN.pdf

Heard, E.M., Auvaa, L., Conway, B. A. (2016). Culture X: Addressing barriers to physical activity in Samoa. Health Promotion International, 32(4), 734-742. doi: 10.1093/heapro/dav1 19

Heart, M. Y., Chase, J., Elkins, J., \& Altschul, D. B. (2011). Historical trauma among Indigenous Peoples of the Americas: Concepts, research, and clinical considerations. Journal of Psychoactive Drugs, 43(4), 282-290. doi: 10.1080/02791072.2011.628913

Heart Research Institute. (2018). First Nations people and heart disease. Retrieved from http://www.hricanada.org/about-heart-disease/first-nations-people-and-heart-disease

Hurdle, D. E. (2001). Social support: A critical factor in women's health and health promotion. Health \& Social Work, 26(2), 72-79. PMID: 11379000 
Jacklin, K. M., Henderson, R. I., Green, M. E., Walker, L. M., Calam, B., \& Crowshoe, L. J. (2017). Health care experiences of Indigenous people living with type 2 diabetes in Canada. Canadian Medical Association Journal, 189(3), E106-E112. doi: 10.1503/cmaj.161098

Johnstone, S. E., \& Baylin, S. B. (2010). Stress and the epigenetic landscape: A link to the pathobiology of human diseases? Nature Reviews Genetics, 11(11), 806-812. doi: 10.1038/nrg2881

Kenny, C., Faries, E., Fiske, J., \& Voyageur C. (2004). A holistic framework for Aboriginal policy research. Retrieved from http://www.turtleisland.org/resources/hresearch.pdf

King, M., Smith. A., \& Gracey, M. (2009). Indigenous health part 2: The underlying causes of the health gap. Lancet, 374(9683), 76-85. doi: 10.1016/S0140-6736(09)60827-8

Klomp, H., Dyck, R. F., \& Sheppard, S. (2003). Description and evaluation of a prenatal exercise program for urban Aboriginal women. Canadian Journal of Diabetes, 27(3), 231-238. Retrieved from http:/citeseerx.ist.psu.edu/viewdoc/download?doi=10.1.1.628.6719\&rep=rep1\&type=pdf

Latimer, M., Sylliboy, J. R., MacLeod, E., Rudderham, S., Francis, J., Hutt-MacLeod, D., ...Finley, G. A. (2018). Creating a safe space for First Nations youth to share their pain. Pain Reports, 3(Suppl 1), e682. doi: 10.1097/pr9.0000000000000682.

Lavallée L. (2008). Balancing the medicine wheel through physical activity. Journal of Aboriginal Health, 4(1), 64-71. Retrieved from https://www.ryerson.ca/asbr/asbr/files/Balancing\%20the\%20Medicine\%20Wheel\%20Through\%2 0Physical\%20Activity.pdf

Lavallée, L. F. (2007). Physical activity and healing through the medicine wheel. Social Work Publications and Research. Paper 2. Retrieved from http://digitalcommons.ryerson.ca/socialwork/2

Lindsay Smith, G., Banting, L., Eime, R., O'Sullivan, G., \& van Uffelen, J. G. Z. (2017). The association between social support and physical activity in older adults: A systematic review. International Journal of Behavioral Nutrition and Physical Activity, 14(1):56. doi: 10.1186/s12966-017-0509-8.

Look AHEAD Research Group. (2014). Eight-year weight losses with an intensive lifestyle intervention: The Look AHEAD study. Obesity (Silver Spring), 22(1), 5-13. doi: 10.1002/oby.20662 
Marrone, S. (2007). Understanding barriers to health care: A review of disparities in health care services among Indigenous populations. International Journal of Circumpolar Health, 66(3),188-198. doi: 10.3402/ijch.v66i3.18254

MBA Learner. (2018). Hawthorne Effect. What is it? Retrieved from https://www.google.com/url?sa=t\&rct=j\&q=\&esrc=s\&source=web\&cd=24\&cad=rja\&uact=8\&ve $\mathrm{d}=2$ ahUKEwis4cOokK_eAhWNyVMKHUhQCPIQFjAXegQIAxAB\&url=https\%3A\%2F\%2Fmb alearner.com\%2Fhawthorne-effect\%2F\&usg=AOvVaw1FdqHLRvLwPuZ60hNhjQ55 [cited 2018 September 3].

McHugh, T. F., \& Kowalski, K. C. (2009). Lessons learned: Participatory action Research with young Aboriginal women. Pimatisiwin: A Journal of Indigenous and Community Health, 7(1), 117-131. Retrieved from https://pdfs.semanticscholar.org/eca2/6c999da633cda69d54ff2fa8439f55c369fe.pdf

Mead, E. L., Gittelsohn, J., Roache, C., Corriveau, A., \& Sharma, S. (2013). A community-based, environmental chronic disease prevention intervention to improve healthy eating psychosocial factors and behaviors in indigenous populations in the Canadian Arctic. Health Education \& Behaviour, 40(5), 592-602. doi: 10.1177/1090198112467793

Mohatt, N. V., Fok, C. C., Burket, R., Henry, D., \& Allen, J. (2011). Assessment of awareness of connectedness as a culturally-based protective factor for Alaska native youth. Cultural Diversity \& Ethnic Minority Psychology, 17(4), 444-55. doi: 1037/a0025456

Murgatroyd, C., Wu, Y., Bockmuhl, Y., \& Spengler, D. (2010). Genes learn from stress: How infantile trauma programs us for depression. Epigenetics, 5(3), 194-199. doi: 10.4161/epi.5.3.11375

Native Women's Association of Canada. (2012). Diabetes self-management toolkit for Aboriginal women. Retried from http://nada.ca/wp-content/uploads/2016/pdfs/NADA\%20Resources/2012NWAC-Diabetes-Toolkit.pdf

Navaneelan, T., \& Janz, T. Adjusting the scales: Obesity in the Canadian population after correcting for respondent bias. Ottawa, ON: Statistics Canada. Retrieved from https://www150.statcan.gc.ca/n1/pub/82-624-x/2014001/article/11922-eng.htm

Ory, M. G., Lee, S., Han, G., Towne, Jr., S. D., Quinn, C., Neher, T.,...Smith M. L. (2018). Effectiveness of a lifestyle intervention on social support, self efficacy, and physical activity among older adults: Evaluation of Texercise Select. International Journal of Environmental Research and Public Health, 15(2), E234. https://doi.org/10.3390/ijerph15020234 
Oster, R. T., Mayan, M. J., \& Toth, E. L. (2014). Diabetes in pregnancy among First Nations women. Qualitative Health Research, 24(11), 1469-1480. doi: 10.1177/1049732314545089

Prince, S. A., McDonnell, L. A., Turek, M. A., Visintini, S., Nahwegahbow, A., Kandasamy, S., ...Coutinho, T. (2018). The state of affairs for cardiovascular health research in Indigenous women in Canada: A scoping review. Canadian Journal of Cardiology, 34(4), 437-449. doi: 10.1016/j.cjca.2017.11.019

Public Health Agency of Canada. (2011a). Diabetes in Canada: Facts and figures from a public health perspective. Retrieved from https://www.canada.ca/content/dam/phac-aspc/migration/phacaspc/cd-mc/publications/diabetes-diabete/facts-figures-faits-chiffres-2011/pdf/facts-figures-faitschiffres-eng.pdf

Public Health Agency of Canada. (2011b). Obesity in Canada. Prevalence among Aboriginal populations. Retrieved from https://www.canada.ca/en/public-health/services/healthpromotion/healthy-living/obesity-canada/prevalence-among-aboriginal-populations.html

Restoule, J.P. (2006). Male Aboriginal identity formation in urban areas: A focus on process and context (Doctoral dissertation). University of Toronto, Toronto, ON.

Rice, K., Te Hiwi, B., Zwarenstein, M., Lavallee, B., Barre, D. E., Harris, S. B., \& FORGE AHEAD Program Team. (2016). Best Practices for the prevention and management of diabetes and obesityrelated chronic disease among Indigenous peoples in Canada: A review. Canadian Journal of Diabetes, 40(3), 216-225. doi: 10.1016/j.jcjd.2015.10.007

Romero-Corral, A., Somers, V. K., Sierra-Johnson, J., Thomas, R.J ., Collazo-Clavell, M. L., Korinek, J.,...Lopez-Jemenez, F. (2008). Accuracy of body mass index in diagnosing obesity in the adult general population. International Journal of Obesity (London), 32(6), 959-966. doi: 10.1038/ijo.2008.11

Rothe, J. P., Ozegovic, D., \& Carroll, L. J. (2009). Innovation in qualitative interviews: "Sharing Circles" in a First Nations community. Injury Prevention, 15(5):334-340. doi: 10.1136/ip.2008.021261

Rowlands, G., Shaw, A., Jaswal, S., Smith, S., \& Harpham, T. (2017). Health literacy and the social determinants of health: A qualitative model from adult learners. Health Promotion International, 32(1), 130-138. doi: 10.1093/heapro/dav093 
Shaw, S. J., Huebner, C., Armin, J., Orzech, K., \& Vivian, J. (2009). The role of culture in health literacy and chronic disease screening and management. Journal of Immigrant and Minority Health, 11(6), 460-467. doi: 10.1007/s10903-008-9135-5

Shilts, M. K., Horowitz, M., \& Townsend, M.S. (2004). Goal setting as a strategy for dietary and physical activity behavior change: A review of the literature. American Journal of Health Promotion, 19(2), 81-93. doi: 10.4278/0890-1171-19.2.81

Sushames, A., van Uffelen, J. G., \& Gebel, K. (2016). Do physical activity interventions in Indigenous people in Australia and New Zealand improve activity levels and health outcomes? A systematic review. International Journal of Behavioral Nutrition and Physical Activity, 13(1), 129. doi: 10.1186/s12966-016-0455-x

Tamers, S. L., Beresford, S. A., Cheadle, A. D., Zheng, Y., Bishop, S. K., \& Thompson, B. (2011). The association between worksite social support, diet, physical activity and body mass index. Preventive Medicine, 53(1-2), 53-56. doi: 10.1016/j.ypmed.2011.04.012

Taylor S., \& McDermott, R. (2010). What do we know about health literacy and diabetes care, and what does this mean for Aboriginal and Torres Straight Islander peoples with diabetes? Aboriginal \& Islander Health Worker Journal, 34(6), 28-30. Retrieved from https://researchonline.jcu.edu.au/36809/1/36809_McDermott_2010.pdf

Teufel-Shone, N. I., Fitzgerald, C., Teufel-Shone, L., \& Gamber, M. (2009). Systematic review of physical activity interventions implemented with American Indian and Alaska Native populations in the United States and Canada. American Journal of Health Promotion, 23(6), S8-32. doi: 10.4278/ajhp.07053151

Tjepkema, M. (2005). Measured obesity. Adult obesity in Canada: Measured height and weight. Ottawa, ON: Statistics Canada. Retrieved from https://www150.statcan.gc.ca/n1/pub/82-620m/2005001/pdf/4224906-eng.pdf

Truth and Reconciliation Commission of Canada. (2015). Honouring the truth, reconciling for the future: Summary of the final report of the Truth and Reconciliation Commisssion of Canada. Retrieved from http://www.trc.ca/websites/trcinstitution/File/2015/Findings/Exec_Summary_2015_05_31_web_o. pdf

Van Duyn, M. A., McCrae, T., Wingrove, B. K., Henderson, K. M., Boyd, J. K., Kagawa-Singer M, ...Maibach, E. W. (2007). Adapting evidence-based strategies to increase physical activity among 
African Americans, Hispanics, Hmong, and Native Hawaiians: A social marketing approach. Preventing Chronic Disease, 4(4), A102. PMID: 17875246; PMCID: PMCPMC2099267

Warburton, D.E., Gledhill, N., Jamnik, V. K., Bredin, S. S., McKenzie, D. C., Stone, J., ...Shephard, R. J. (2011). Evidence-based risk assessment and recommendations for physical activity clearance: Consensus Document 2011. Applied Physiology, Nutrition \& Metabolism, 36(Suppl 1), S266-298. doi: $10.1139 / \mathrm{h} 11-062$

Werch, C. E., Bian, H., Moore, M. J., Ames, S., DiClemente, C. C., \& Weiler, R. M. (2007). Brief multiple behavior interventions in a college student health care clinic. Journal of Adolescent Health, 41(6), 577-585. doi: 10.1016/j.jadohealth.2007.06.003

Wicklum, S., Sampson, M., Willis, E., Henderson, R., Amson, A., Wiart, S.,...McBrien, K. (2018). A systematic literature review of physical activity-based health programs for Indigenous women: Impacts on physical activity levels, obesity, and community building. Manuscript submitted for publication.

World Health Organization. 2018. WHO launches ACTIVE: a toolkit for countries to increase physical activity and reduce noncommunicable diseases. Retrieved from http://www.who.int/topics/physical_activity/en/.

Yehuda, R., Daskalakis, N. P., Bierer, L. M., Bader, H. N., Klengel, T., Holsboer, F., \& Binder, E. B. (2016). Holocaust exposure induced intergenerational effects on FKBP5 methylation. Biological Psychiatry, 80(5), 372-80. doi: 10.1016/j.biopsych.2015.08.005

Young, T. K., Reading, J., Elias, B., \& O'Neil, J. D. (2000). Type 2 diabetes mellitus in Canada's First Nations: Status of an epidemic in progress. Canadian Medical Association Journal, 163(5), 561566. PubMed PMID: 11006768. PMID: 11006768; PMCID: PMC80466

Ziabakhsh, S., Pederson, A., Prodan-Bhalla, N., Middagh, D., \& Jinkerson-Brass, S. (2016). Womencentered and culturally responsive heart health promotion among Indigenous women in Canada. Health Promotion Practice, 17(6):814-26. doi: 10.1177/1524839916633238 


\section{Appendices}

\section{Appendix: Pre-Program Questionnaire}

\section{Women Warriors Questionnaire}

Name: Date of Birth(dd/mm/yyyy):

Phone Number: (home) (cell):

Home address:

Email address:

City: Province: Postal Code:

AB/SK Health Card \#: Family Doctor:

\section{Ethnicity:}

$\square$ Arab $\square$ Black $\square$ Chinese $\square$ Caucasian $\square$ First Nations (Circle one: Urban or
Treaty) $\square$ Inuit $\square$ Metis $\square$ Korean $\square$ Japanese $\square$ Latin American
Southeast Asian $\square$ West Asian $\square$ Other (please specify):

\section{$\underline{\text { Health Information (Filled out by nurse) }}$}

My current weight is My height is

Do you want to lose/gain weight? Yes No

If yes, my goal weight is:

Measurements: Waist Hips BMI

Blood Pressure

\section{$\underline{\text { Medical History }}$}

Please tell us what health conditions you have, and when you were told by a doctor. Check the first column for all the conditions that apply to you: 


\begin{tabular}{|c|c|c|}
\hline & What condition do you have? & $\begin{array}{l}\text { When were you told? } \\
\text { (month, vear) }\end{array}$ \\
\hline$\underline{\underline{ }}$ & Heart disease (including high blood pressure, high cholesterol) & \\
\hline$\underline{\underline{ }}$ & $\underline{\text { Cancer }}$ & \\
\hline$\underline{\underline{ }}$ & Diabetes: (Please cirlcle) Type I Type II Prediabetic & \\
\hline$\underline{\underline{ }}$ & $\frac{\text { Disease of the lungs (e.g. asthma, tuberculosis, emphysema, }}{\underline{\text { COPD) }}}$ & \\
\hline$\underline{\underline{ }}$ & Bone and/or joint disease & \\
\hline$\underline{\underline{ }}$ & $\underline{\text { Kidney and urinary tract disease }}$ & \\
\hline 므 & Liver disease (e.g. hepatitis) & \\
\hline$\underline{\underline{ }}$ & Mental illness & \\
\hline$\underline{\underline{ }}$ & Other, what is it? & \\
\hline
\end{tabular}

Please list all your medications and dosage here:

International Journal of Indigenous Health, Volume 14, Issue 2, 2019. • 198 
Do you take vitamins or herbal supplements? Yes No If yes, please list:

Do you smoke? Yes No If yes, how many cigarettes in an average week?

Do you drink alcohol? Yes No

One drink $=5 \mathrm{oz}$ wine $(150 \mathrm{ml}), 1.5 \mathrm{oz}(45 \mathrm{ml})$ liquor, $12 \mathrm{oz}(360 \mathrm{ml})$ beer

If yes, how many in an average week?

\section{Blood Glucose Monitoring}

Do you check your blood sugar at home? Yes No

Do you experience low blood sugars? Yes No If yes, how many per week?

\section{$\underline{\text { Exercise }}$}

How would you rate your level of physical activity at work?

$\begin{array}{llllll}1 & 2 & 3 & 4 & 5\end{array}$

$1=$ seated most of the day at a desk e.g. Desk job

3 = standing most of the day e.g. teacher standing in front of a classroom

$5=$ physically active most of the day e.g. nurse on ward duty 
OVER AND ABOVE YOUR WORK, please indicate your physical activity in the table below OVER THE LAST WEEK.



International Journal of Indigenous Health, Volume 14, Issue 2, 2019. 200 







\begin{tabular}{|l|l|l|}
\hline Lacrosse Yoga & & \\
Martial Arts & & \\
\hline Home Activities & & \\
House Work & & \\
Gardening & & \\
Carpentry, painting, wallpapering & & \\
Playing with children & & \\
\hline
\end{tabular}

How many minutes do you spend exercising per day?

Sunday __ Monday _ Tuesday _ Wednesday _ Thursday _ Friday _ Saturday _ TOTAL MINUTES PER WEEK

Please choose the best statement to describe your physical activity over the last 3 months:

a. Roughly similar to that given above

b. Less than that given above

c. More than that given above

d. I have not been able to do any planned physical activity in the last 3 months

Over the last 3 months have you been prevented from exercise because of your health?

Yes No

If yes, please circle all of the factors that prevent you from exercising:

a. Your weight 
b. Arthritis or joint pain

c. Trauma to arms or legs

d. Stroke or spinal cord injury

e. Lack of interest

f. Dislike

g. Asthma or emphysema

h. Heart problems

Do you regularly use a pedometer? Yes No

If yes, how many steps did you average per day OVER THE LAST WEEK (count all steps including those at work)?

\section{Coping (Please circle best answer)}

I am confident that I can make lifestyle changes to successfully manage my weight?

Stronglydisagree Disagree Neutral Agree Stronglyagree

Circle any of the following words that describe how you currently feel about your health and how it affects you:

Overwhelmed Out of control Alone Angry Ok Not a problem

What is your greatest fear regarding your current state of health? 
Confidentiality: All results of the study will be kept confidential. I am aware that the results of this program mav be analvsed in the future solely for research purposes. I will not be identifiable in any publications or presentations resulting from this study. All information will be coded and I will not be identified by name. No records bearing my name will leave the control of Shellev Wiart, the co-ordinator of this program.

Voluntary Participation: I am free to withdraw from this study at any time. If I have concerns about my rights as a program participant I may contact Shelley Wiart at (780) 872-0877 OR Shellev@womenwarriors.club.

Patient's Name (Please Print)

Patient's Signature

Date

$\underline{\text { Name of Delegate (Please Print) }}$

Signature of Delegate

Date 